\title{
Study of Delay Cultivation on Seed Yield and Seed Quality of Canola (Brassica Napus L.) Genotypes
}

Asadollah Gholamian ${ }^{1 *}$ and Mahdi Bayat ${ }^{2}$

${ }^{1}$ Department of Biology, Mashhad Branch, Islamic Azad University, Mashhad, Iran

${ }^{2}$ Department of Agriculture, Mashhad Branch, Islamic Azad University, Mashhad, Iran

\begin{abstract}
In order to study the effects of delay cultivation on seed yield and germination parameters in canola, an experiment was conducted in Torbat-Jam region during 2010-2011. The experimental design was a split plot arranged in RCBD with three replications. Three sowing dates (6 September, 7 October and 6 November) were assigned to main plots and three canola genotypes (Hyola 401, Zarfam and Mudena) were randomized to subplots. The results of variance analysis about yield components showed genotypes, sowing dates and their interactions had significant effects on all agronomical traits. Also delaying in culture leads to decrease yield components and seed yield subsequently. However, the remarkable point was that genotypes could affect seed yield more than sowing dates; so seed yield, to change genotype from Hyola 401 to Modena, decreased $40 \%$; whereas to change sowing date from 6 September to 6 November, decreased $10 \%$. The results of variance analysis about germination parameters showed that genotypes, sowing dates and their interaction had significant effects on germination parameters. In other hands, sowing dates were more effective on qualification and seed vigor than genotypes. As a conclusion, genotypes and sowing dates affected seed yield and seed quality significantly, therefore, produced seed of cultivated crops in appropriate date will were more vigorous which will increase canopy and growth rate at next year cultivation.
\end{abstract}

Keywords: Agronomical traits; Germination parameters; Germination test; Sowing date

\section{Introduction}

Canola is one of the most important oil seed that developing in two recent decades extremely. Canola after soybeen is the second oil plant in the world [1]. Reaching maximum yield needs to select strong seeds with high quality. Selection of high quality seeds is essential for more stability and growth. It is clear that seed vigour is dependent on some factors such as sowing date, temperature, humidity, drought, diseases, pathogens and genetic factors [2]. So selection of appropriate sowing date is important for cold resistant in winter and scape from high temperature and unfavorite conditions at the end of growth period. In other hands, the successful passing of winter in canola is due to formation of advanced root system; which is dependent on sowing dates [3]. Elias et al. [4] reported that factors such as sowing date, genotype, ripening stage, gathering stages, method of gathering, seed desiccation and storage conditions are effective on seed quality. At the present study is tryed to determine the best sowing date and genotype in Torbat-jam.

\section{Materials and Methods}

In order to study the effects of delay cultivation on seed yield and germination parameters in canola, an experiment was conducted in Torbat-jam during 2010-2011. Torbat-Jam region locate in 35'15" Latitude, 60.35" longitude and 950.4 meters above sea level. The experimental design was a split plot arranged in RCBD with three replications. Three sowing dates $(6$ September, 7 October and 6 November) were assigned to main plots and three canola genotypes (Hyola 401, Zarfam and Mudena) were randomized to subplots (Hyola 401 is a spring and hybrid genotype (single cross) and cultivate in warm and moist regions commonly. However, Mudena and Zarfam are winter genotypes and cultivate in cold and moderate regions commonly). Each plot has eight rows ( $5 \mathrm{~m}$ length). Distance between each row was 25 $\mathrm{cm}$ and seeds implanted on rows by $8 \mathrm{~cm}$ distances from each other. To evaluate agronomy traits, 10 plants were selected randomly. Then the averages of the traits were used to analysis. To study germination parmeters, the seeds are provided from three genotypes in three sowing dates separately. The experimental design was a factorial arranged in CRD with three replications in laboratory. Results analysis is done by SAS ver. 9.12 software.

\section{Results}

The result of variance analysis in agronomy traits indicated significant differences between sowing dates, canola genotypes and their interactions (Table 1). Also, the results of means comparisons of interaction between sowing dates and canola genotypes (Table 2) indicated that Hyola401 has cultivated at 6 September had the best performance in many traits including: number of sub-branches, number of pod, 1000 seed weight, oil content and especially seed yield; whereas Mudena has cultivated at 6 November had the worst performance in many agronomy traits (Table 2). The result of correlation coefficients indicated that there are significant and positive relations between seed yield with number of sub-branches, number of pod, pod diameter, number of seed in pod, 1000 seed weight and oil content, whereas there are significant and negative relations between seed yield with pod length and protein content (Table 3).The results of variance analysis for germination parameters indicated that there is significant difference between sowing dates and genotypes in all traits. Also, there is significant difference between interaction of genotypes and sowing dates regard to all traits except root and stem lenght (Table 4). The result

*Corresponding author: Asadollah Gholamian, Department of Biology, Mashhad Branch, Islamic Azad University, Iran, E-mail: Gholamian.academia@yahoo.com

Received January 18, 2013; Accepted January 20, 2013; Published April 20, 2013

Citation: Gholamian A, Bayat M (2013) Study of Delay Cultivation on Seed Yield and Seed Quality of Canola (Brassica Napus L.) Genotypes. Agrotechnol 2: 108. doi:10.4172/2168-9881.1000108

Copyright: (c) 2013 Gholamian A, et al. This is an open-access article distributed under the terms of the Creative Commons Attribution License, which permits unrestricted use, distribution, and reproduction in any medium, provided the original author and source are credited. 
Citation: Gholamian A, Bayat M (2013) Study of Delay Cultivation on Seed Yield and Seed Quality of Canola (Brassica Napus L.) Genotypes. Agrotechnol 2: 108. doi:10.4172/2168-9881.1000108

Page 2 of 3

\begin{tabular}{|c|c|c|c|c|c|c|c|c|c|c|c|}
\hline \multirow[t]{2}{*}{ S.O.V } & \multirow[t]{2}{*}{ Df } & \multicolumn{10}{|c|}{ MS } \\
\hline & & $\begin{array}{l}\text { Seed yield } \\
(\mathrm{kg} / \mathrm{ha})\end{array}$ & Plant height & $\begin{array}{l}\text { Number of } \\
\text { subbranches }\end{array}$ & $\begin{array}{l}\text { Number of } \\
\text { pod }\end{array}$ & $\begin{array}{l}\text { Pod } \\
\text { length }\end{array}$ & $\begin{array}{l}\text { Pod } \\
\text { diameter }\end{array}$ & $\begin{array}{l}\text { Number } \\
\text { of seed }\end{array}$ & $\begin{array}{l}1000 \\
\text { Seed }\end{array}$ & Oil percentage & $\begin{array}{l}\text { Protein } \\
\text { percentage }\end{array}$ \\
\hline Row & 2 & $634345.3^{* *}$ & $314.5 \mathrm{~ns}$ & $0.25 \mathrm{~ns}$ & $389.1^{* *}$ & $0.55^{*}$ & $1.01^{* *}$ & $0.72^{* *}$ & $0.04 \mathrm{~ns}$ & $3.19^{\star \star}$ & $3.07^{\star *}$ \\
\hline Sowing date & 2 & $167435.1^{*}$ & $271.6 \mathrm{~ns}$ & $0.96^{*}$ & $356.7^{* *}$ & $1.2^{*}$ & $2.03^{* *}$ & $0.49^{*}$ & $0.18^{*}$ & 0.03 ns & $0.25^{*}$ \\
\hline MSEa & 4 & 18087.7 & 94.4 & 0.06 & 18.6 & 0.08 & 0.02 & 0.03 & 0.03 & 0.53 & 0.12 \\
\hline genotype & 2 & $2663417.3^{*}$ & $1912.7^{* *}$ & $7.25^{\star *}$ & $3438.3^{* *}$ & $1.70^{\star *}$ & $9.84^{* *}$ & $50.95^{* *}$ & $50.95^{\star \star}$ & $14.56^{* *}$ & $17.58^{* *}$ \\
\hline genotype* Date & 4 & 184731.3* & $397.4^{* *}$ & $0.14^{*}$ & $480.1^{* *}$ & $0.15^{*}$ & $3.22^{* \star}$ & $0.92^{*}$ & $0.92^{*}$ & $1.16^{\star \star}$ & $1.24^{* *}$ \\
\hline MSE & 12 & 38599.3 & 55.9 & 0.03 & 80.7 & 0.07 & 0.25 & 0.20 & 0.20 & 0.12 & 0.20 \\
\hline CV\% & --- & 18.8 & 16.3 & 13.8 & 16.4 & 14.9 & 19.9 & 13.6 & 13.6 & 4.86 & 9.8 \\
\hline
\end{tabular}

Ns: not significant, *: $\mathrm{P}<0.05$ and ${ }^{* *}: \mathrm{P}<0.01$

Table 1: Variance analysis of yield and yield components in canola genotypes.

\begin{tabular}{|c|c|c|c|c|c|c|c|c|c|c|c|}
\hline genotypes & Sowing dates & $\begin{array}{l}\text { Seed yield } \\
(\mathrm{kg} / \mathrm{ha})\end{array}$ & $\begin{array}{l}\text { Plant height } \\
(\mathrm{cm})\end{array}$ & $\begin{array}{l}\text { Number of } \\
\text { sub-branches }\end{array}$ & $\begin{array}{l}\text { Number of } \\
\text { pod }\end{array}$ & $\begin{array}{l}\text { Pod length } \\
(\mathrm{cm})\end{array}$ & $\begin{array}{l}\text { Pod diameter } \\
(\mathrm{mm})\end{array}$ & $\begin{array}{l}\text { Number of } \\
\text { seed in pod }\end{array}$ & $\begin{array}{l}1000 \text { Seed } \\
\text { weight }\end{array}$ & $\begin{array}{l}\text { Oil } \\
\text { percentage }\end{array}$ & $\begin{array}{l}\text { Protein } \\
\text { percentage }\end{array}$ \\
\hline \multirow[t]{3}{*}{ Mudena } & 6 September & 1847.2 cde & $141 \mathrm{a}$ & $4.1 \mathrm{~cd}$ & $128.3 \mathrm{de}$ & $5.7 \mathrm{~b}$ & $4.3 \mathrm{de}$ & $15.5 \mathrm{a}$ & $3.2 \mathrm{bc}$ & $37.9 \mathrm{~cd}$ & $25.8 \mathrm{ab}$ \\
\hline & 15 October & $1630.4 \mathrm{de}$ & $130.3 a b$ & $4.3 \mathrm{c}$ & 118 e & $6.5 \mathrm{a}$ & $4.0 \mathrm{de}$ & $14.3 \mathrm{~b}$ & $3.3 \mathrm{bc}$ & $37.5 \mathrm{~d}$ & $26.2 \mathrm{a}$ \\
\hline & 6 November & $1432.4 \mathrm{e}$ & 123.6 abc & $3.7 \mathrm{~d}$ & 110.3 e & $5.7 \mathrm{~b}$ & $3.3 \mathrm{e}$ & $15.1 \mathrm{ab}$ & $2.6 \mathrm{c}$ & $38.2 \mathrm{~cd}$ & $26.6 \mathrm{a}$ \\
\hline \multirow[t]{3}{*}{ Hyola401 } & 6 September & 2786.7 a & $131.6 \mathrm{ab}$ & $6.1 \mathrm{a}$ & $170.3 \mathrm{a}$ & $4.7 \mathrm{c}$ & $5.9 a b$ & $9.8 \mathrm{e}$ & $4.2 \mathrm{a}$ & $40.5 a$ & $23.2 \mathrm{e}$ \\
\hline & 15 October & $2570.6 \mathrm{ab}$ & $122.3 \mathrm{abc}$ & $6.0 \mathrm{a}$ & $162.3 \mathrm{ab}$ & $5.5 \mathrm{~b}$ & $6.5 \mathrm{a}$ & $10.3 e$ & $4.0 \mathrm{ab}$ & $40.0 \mathrm{a}$ & $23.8 \mathrm{ed}$ \\
\hline & 6 November & $2760.5 a b$ & $105.3 \mathrm{~cd}$ & $5.3 \mathrm{~b}$ & $140.3 \mathrm{~cd}$ & $5.2 \mathrm{bc}$ & $5.5 \mathrm{abc}$ & $10.5 \mathrm{e}$ & $3.6 a b$ & $40.5 a$ & $23.4 \mathrm{ed}$ \\
\hline \multirow[t]{3}{*}{ Zarfam } & 6 September & 2297.1 bc & $100.3 d$ & $5.2 \mathrm{~b}$ & $130.3 \mathrm{cde}$ & $5.2 \mathrm{bc}$ & $5.5 \mathrm{abc}$ & $11.6 \mathrm{~d}$ & $3.4 \mathrm{~b}$ & $39.5 a b$ & $25.0 \mathrm{bc}$ \\
\hline & 15 October & $2716.2 \mathrm{ab}$ & $94.0 \mathrm{~d}$ & $4.6 \mathrm{c}$ & $150.6 \mathrm{abc}$ & $5.7 \mathrm{~b}$ & $5.1 \mathrm{bcd}$ & $12.5 \mathrm{~cd}$ & $3.3 \mathrm{bc}$ & $40.4 \mathrm{a}$ & $24.4 \mathrm{~cd}$ \\
\hline & 6 November & $2022.6 \mathrm{~cd}$ & $113.6 \mathrm{bcd}$ & $4.6 \mathrm{c}$ & 146.6 bcd & $5.4 \mathrm{~b}$ & $4.4 \mathrm{~cd}$ & $12.7 \mathrm{c}$ & $3.8 a b$ & 38.9 bc & $23.4 \mathrm{de}$ \\
\hline
\end{tabular}

Table 2: Means comparisons of interactions between sowing dates and canola cultivars in agronomy traits.

\begin{tabular}{|c|c|c|c|c|c|c|c|c|c|}
\hline traits & Plant height & $\begin{array}{l}\text { Number of } \\
\text { sub-branches }\end{array}$ & Number of pod & Pod length & $\begin{array}{l}\text { Pod } \\
\text { diameter }\end{array}$ & $\begin{array}{l}\text { Number of } \\
\text { seed in pod }\end{array}$ & $\begin{array}{l}1000 \text { Seed } \\
\text { weight }\end{array}$ & $\begin{array}{l}\text { Oil } \\
\text { percentage }\end{array}$ & \\
\hline Seed Yield & $-0.47 \mathrm{~ns}$ & $0.83^{* *}$ & $0.84^{* *}$ & $-0.66^{*}$ & $0.88^{* *}$ & $0.88^{* *}$ & $0.7^{*}$ & $0.95^{\star *}$ & $-0.84^{* *}$ \\
\hline Plant height & 1 & $-0.13 \mathrm{~ns}$ & $-0.13 \mathrm{~ns}$ & $0.22 \mathrm{~ns}$ & $-0.25 \mathrm{~ns}$ & $0.39 \mathrm{~ns}$ & $0.03 \mathrm{~ns}$ & $-0.56 \mathrm{~ns}$ & $0.33 \mathrm{~ns}$ \\
\hline Number of sub-branches & & 1 & $0.84^{* *}$ & $-0.67^{*}$ & $0.96^{* *}$ & $-0.95^{\star *}$ & $0.88^{* *}$ & $0.78^{*}$ & $-0.78^{*}$ \\
\hline Number of pod & & & 1 & $-0.60 \mathrm{~ns}$ & $0.83^{* *}$ & $-0.81^{* *}$ & $0.88^{\star *}$ & $0.78^{*}$ & $-0.88^{* *}$ \\
\hline Pod length & & & & 1 & $-0.60 \mathrm{~ns}$ & $0.72^{*}$ & $-0.55 \mathrm{~ns}$ & $-0.75^{*}$ & $-0.70^{*}$ \\
\hline Pod diameter & & & & & 1 & $-0.90^{* *}$ & $0.80^{* *}$ & $0.81^{* *}$ & $-0.76^{*}$ \\
\hline Number of seed in pod & & & & & & 1 & $-0.81^{* *}$ & $-0.90^{* *}$ & $0.86^{\star \star}$ \\
\hline 1000 Seed weight & & & & & & & 1 & $0.59 \mathrm{~ns}$ & $-0.86^{* *}$ \\
\hline Oil percentage & & & & & & & & 1 & $-0.81^{* *}$ \\
\hline
\end{tabular}

Ns: not significant, *: $\mathrm{P}<0.05$ and ${ }^{* *}: \mathrm{P}<0.01$

Table 3: Phenotypic correlation coefficient among agronomy traits in canola.

of meas comparison for interaction between genotypes and sowing dates indicated that Hyola 401 cultivated at 6 September and 7 October has the best quality at all germination parameters, whereas Mudena has cultivated at 6 November has the least quality (Table 5). The result of correlation coefficient for germination parameters indicated that there were significant and positive relations between all germination parameters (Table 6).

\section{Discussion}

\section{Yield and yield components}

According to the present study, it is determined that canola genotypes have contradictory reaction to sowing date, as that in early sowing dates some genotypes were tall and another was short; this is due to genetic variations and adaptation differences among genotypes. In other hands, it was observed that delay cultivation led to reducing in number of sub-branches and number of pod in all genotypes; it is probably due to shortening of vegetative period and lack of enough time to growth. Niknam et al. [5] stated that delay cultivation led to shortening of vegetative period and unfavorable conditions at the end of growth season such as heat and drought; it caused, at last, would reduce number of pod and seed yield significantly. In this study, it was showed negative relation between number of seed in pod and 1000 seed weight, so more seeds in pod led to less 1000 seed weight. This result seems to be logical, because since sources of photosynthetic producer are constant, more seed received less photosynthetic material whereas less seed received more photosynthetic materials. Mendham et al. [6] stated that letar cultivation caused to coinciding seed growth period with high temperature of season that lead to decrease in photosynthetic productions, shortening of seed growth period, accelerating of ripening period and subsequent lead to reduction in 1000 seed weight and seed yield. Finally, it revealed that dilatary cultivation reduced yield components such as number of sub-branchs, pod diameter, 1000 seed weight and oil content, so overall seed yield surely reduced. So these traits regard as the most important yield components that their improvements lead to improvement of seed yield. Anyway, it should rememberd that different genotypes effect on seed yield is rather than different sowing dates effect, because changing of genotypes from Hyola 401 to Mudena, seed yield reduced from 2705.93 to $1636.66 \mathrm{Kg} /$ ha (about 40\%), whereas changing sowing dates from 6 Septmber to 6 November, seed yield reduced from 2310 to $2071 \mathrm{Kg} / \mathrm{ha}$ (about 10\%); these results approved the results of Farre et al. [7]. 
Citation: Gholamian A, Bayat M (2013) Study of Delay Cultivation on Seed Yield and Seed Quality of Canola (Brassica Napus L.) Genotypes. Agrotechnol 2: 108. doi:10.4172/2168-9881.1000108

Page 3 of 3

\begin{tabular}{|c|c|c|c|c|c|c|}
\hline \multirow[b]{2}{*}{ S.O.V } & \multicolumn{6}{|c|}{ MS } \\
\hline & Germination percentage & Germination rate & Vigor of germination & root lenght & stem lenght & Seedling lenght \\
\hline genotypes & $182.3^{* *}$ & $177.6^{* *}$ & $232.6^{* *}$ & $1.0^{* *}$ & $0.16^{* *}$ & $1.9^{* *}$ \\
\hline Sowing time & $235.7^{* *}$ & $246.9^{* *}$ & $354.5^{\star *}$ & $1.1^{* *}$ & $0.19^{* *}$ & $2.1^{* *}$ \\
\hline Sowing time $\times$ genotypes & $15.6^{\star *}$ & $26.9^{* *}$ & $25.0^{* *}$ & 0.2 & 0.02 & $0.3^{* *}$ \\
\hline MSE & 3.1 & 5.0 & 3.5 & 0.1 & 0.01 & 0.1 \\
\hline CV (\%) & 5.0 & 10.1 & 9.6 & 7.4 & 5.3 & 5.1 \\
\hline
\end{tabular}

Ns: not significant, *: $\mathrm{P}<0.05$ and ${ }^{* *}: \mathrm{P}<0.01$

Table 4: Variance analysis of germination parameters in three canola genotypes.

\begin{tabular}{|c|c|c|c|c|c|c|c|}
\hline genotypes & Sowing date & $\begin{array}{l}\text { Germination } \\
\text { percentage }\end{array}$ & Germination rate & Vigor of germination & root lengh & stem lengh & Seedling lengh \\
\hline \multirow[t]{3}{*}{ Mudena } & 6 September & $86.33 b$ & $27.53 b$ & $23.78 \mathrm{~b}$ & $4.54 \mathrm{a}$ & $3.36 a b$ & $7.91 \mathrm{a}$ \\
\hline & 15 October & $83.33 \mathrm{bc}$ & $21.48 \mathrm{c}$ & $17.91 \mathrm{c}$ & $3.89 \mathrm{bc}$ & $3.14 \mathrm{bc}$ & $7.03 \mathrm{ab}$ \\
\hline & 6 November & $80.67 \mathrm{c}$ & 20.66 c & $16.71 \mathrm{c}$ & $3.7 \mathrm{c}$ & $3.09 \mathrm{bc}$ & $6.78 \mathrm{~b}$ \\
\hline \multirow[t]{3}{*}{ Hyola401 } & 6 September & $97.00 \mathrm{a}$ & $35.52 \mathrm{a}$ & $34.81 \mathrm{a}$ & $4.74 \mathrm{a}$ & $3.49 \mathrm{a}$ & $8.22 \mathrm{a}$ \\
\hline & 15 October & 93.67 a & $35.91 \mathrm{a}$ & $31.8 \mathrm{a}$ & $4.73 \mathrm{a}$ & $3.47 \mathrm{a}$ & $8.24 \mathrm{a}$ \\
\hline & 6 November & $86.00 \mathrm{~b}$ & 24.9 bc & $21.39 \mathrm{bc}$ & $4.57 \mathrm{a}$ & $3.36 \mathrm{ab}$ & $7.92 \mathrm{a}$ \\
\hline \multirow[t]{3}{*}{ Zarfam } & 6 September & $93.33 \mathrm{a}$ & $34.47 \mathrm{a}$ & $33.63 \mathrm{a}$ & $4.78 \mathrm{a}$ & $3.51 \mathrm{a}$ & $8.25 \mathrm{a}$ \\
\hline & 15 October & $85.67 \mathrm{~b}$ & $27.7 \mathrm{~b}$ & $23.74 \mathrm{~b}$ & $4.34 a b$ & $3.29 \mathrm{abc}$ & $7.63 \mathrm{a}$ \\
\hline & 6 November & $79.33 c$ & $20.47 \mathrm{c}$ & $16.47 \mathrm{c}$ & $3.76 \mathrm{bc}$ & $3.04 \mathrm{c}$ & $6.79 b$ \\
\hline
\end{tabular}

Table 5: Meas comparison for interaction between genotypes and sowing dates in germination parameters.

\begin{tabular}{|l|l|l|l|l|l|}
\hline Traits & $\begin{array}{l}\text { Germination } \\
\text { rate }\end{array}$ & $\begin{array}{l}\text { Vigor of } \\
\text { germination }\end{array}$ & $\begin{array}{l}\text { Root } \\
\text { lenght }\end{array}$ & $\begin{array}{l}\text { stem } \\
\text { lenght }\end{array}$ & $\begin{array}{l}\text { Seedling } \\
\text { lenght }\end{array}$ \\
\hline $\begin{array}{l}\text { Germination } \\
\text { percentage }\end{array}$ & $0.97^{* *}$ & $0.98^{* *}$ & $0.87^{* *}$ & $0.94^{* *}$ & $0.91^{* *}$ \\
\hline Germination rate & 1 & $0.99^{* *}$ & $0.89^{* *}$ & $0.93^{* *}$ & $0.93^{* *}$ \\
\hline Vigor of germination & & 1 & $0.85^{* *}$ & $0.96^{* *}$ & $0.90^{* *}$ \\
\hline Root lenght & & & 1 & $0.99^{* *}$ & $0.99^{* *}$ \\
\hline stem lenght & & & & 1 & $0.99^{* *}$ \\
\hline
\end{tabular}

* : $\mathrm{P}<0.05$ and ${ }^{* *}: \mathrm{P}<0.01$

Table 6: Phenotpice correlation coefficient of germination parameters in canola.

\section{Germination parameters}

We observed that producted seeds of different sowing dates had significant differences in germination parameters; on the late sowing date the seed quality was low. While cultivated seed in suit sowing date due to has more favorite growth conditions has more seed quality and vigour. Elias and Copland [8] stated that percent of germination is affected severly by seed quality, and it is necessary to use standard germination test to determine seed quality and vigour in canola. At the present paper is observed seeds had higher germination percentage, had fast germination rate and longer seedling length. In this way, Hyola 401 and Zarfam cultivated at 6 September due to enough time to growth could produce higher quality seeds with longer seedling length. Hampton and Tekrony [9] showed there is significant positive correlation between seedling length and seed quality. They, at last, reported seedling length is an index to evaluate quality of seedling. The vigour of germination is a very important parameter in germination test, because it calculated by multiplying length of seedling to germination percent. So the seeds had higher seedling length and more germination percent the seeds had higher vigour of germination. Also it is distinguished, at this study, vigour of germination is effected more sowing date rather than genotype.

\section{Conclusion}

The results of this study indicated that 6 September is the best sowing date for canola in Torbat-jam region, so the cultivation is done later the traits such as number of sub-branches, number of pod, oil content,

1000 seed weight and seed yield are worse. Also the results showed that delay cultivation lead to decreasing of seed qualities (germination percent, seedling length, vigour of germination, etc). So the seeds with high quality are producted only in genotypes cultivated in suit sowing date. At last, we recommended Hyola401 and 6 September as desirable genotype and perfect sowing date in Torbat-jam region.

\section{References}

1. FAO (2007) FAO Statistic Service.

2. Gusta LV, Johnson EV, Nesbitt NT, Klikland KJ (2003) Effect of seeding date on canola seed quality and seed vigour. Can J Plant Sci 84: 463-471.

3. Laaniste P, Joudu J, Eremeev V, Maeorg E (2007) institute of Agricultural and environmental science, stonian university of life science, tarto estonia.acta agricultural scandinavia section b-soil and plant science, 57: 342-348.

4. Elias S, Garary A, Schweitzer L, Henning S (2006) Seed quality testing of native species. Native Plants Journal 7: 15-19.

5. Niknam S, Ma RO, turner DW (2003) Osmatic adjustment seed yield of Brassica napus B. juneed genotypes in a water limited environment in sout Western Australia. Aus J of Experimental agriculture 43:1127-1135.

6. Mendham NJ, Shipway PA, Scott RK (1981) The effects of delayed sowing and weather on growth, development and yield of winter oil-seed rape (Brassica napus). J Agric Sci 96: 389-416.

7. Farre MJ, Robertson G, Walton H, Asseng S (2002) The effect of delayed sowing and weather on growth, development and yield of winter oilseed rape (Brassica napus L.). Aust J Agric Res 53: 1155-1164.

8. Elias SG, Copleland Lo (1994) The effect of storage condition on canola (Brassica Napus L.) seed quality. Journal of Seed Technology 18: 21-29.

9. Hampton JG, Tekrony DM (1995) Handbook of vigour test methods. (3rdedn) International Seed Testing Assocition (ISTA). Zurich, Switzerland. 